\title{
THE EFFECTS OF DIMMER CONTROLLED ATMOSPHERIC PRESSURE PLASMA JET TO THE BIOPHYSICAL STRUCTURES OF HeLa CELLS
}

\author{
CHIN FHONG SOON ${ }^{1 *}$, NAFARIZAL NAYAN ${ }^{1}$, NAZNIN SULTANA ${ }^{2}$, MARLIA MORSIN ${ }^{1}$, \\ GIM PAO LIM ${ }^{1}$, NYUK LING MA ${ }^{3}$, ELFA RIZAN RIZON ${ }^{1}$ and KIAN SEK TEE ${ }^{1}$ \\ ${ }^{1}$ Biosensor and Bioengineering Laboratory, Microelectronics and \\ Nanotechnology-Shamsuddin Research Center, IIE, \\ Universiti Tun Hussein Onn Malaysia, 86400 Parit Raja, \\ Batu Pahat, Johor, Malaysia \\ ${ }^{2}$ Medical Academy, Prairie View A\&M University, TX 77446, USA \\ ${ }^{3}$ Faculty of Science and Marine Environment, University Malaysia Terengganu, \\ 21030 Kuala Nerus, Terengganu, Malaysia \\ "E-mail: soon@uthm.edu.my
}

Accepted 13 October 2020, Published online 25 December 2020

\begin{abstract}
Non-thermal atmospheric pressure plasma jet (NTAPPJ) was shown as a promising tool for sterilization, treatment of chronic wounds \& tumors. A portable and facile NTAPPJ system will broaden the application of plasma for many other biomedical applications. This paper demonstrates the feasibility of a customized dimmer controllable atmospheric pressure plasma jet (APPJ) in treating HeLa cells. A plasma torch was energized at $8 \mathrm{kVpp}$ and $35 \mathrm{kHz}$ from a neon transformer and discharged with argon gas-producing plasma plume of various gas species. The output intensity of the plasma discharge was adjusted by the voltage input from the dimmer controller circuit. Between $60-220 \mathrm{~V}$, a different power output of the dimmer can be varied between 8.4 to $83.6 \mathrm{~W}$, to generate different intensities of non-thermal APPJ (NTAPPJ). The NTAPPJ was then applied to HeLa cells for $20 \mathrm{sec} \&$ it was found that cells reduced their adhesion at a dimmer power $<20 \mathrm{~W}$ but stayed viable. This progressed to observations of damaged cell body when the power was increased beyond $20 \mathrm{~W} \&$ the cell membranes shattered when the power was up to $83.6 \mathrm{~W}$. This was due to the ultraviolet rays and reactive oxygen species (ROS), that induced detrimental effects to the cells. The controllable NTAPPJ system, based on dimmer control, induced different levels of effects on the biophysical structures of cells, ranging from reduced cell spread to apoptosis and eventually cell membrane disintegration.
\end{abstract}

Key words: Atmospheric plasma jet, HeLa cells, dimmer, argon gas, plasma medicine, apoptosis

\section{INTRODUCTION}

Plasma is the ionization of gases discharged under high electrical energy. Positive ions, electrons, ultraviolet (UV) rays \& other activated species in the plasma generated, are released in balancing to the atoms and molecules ionized in vacuum or atmospheric air (Scholtz et al., 2015). These species are usually chemically reactive when interacting with solid or liquid (Siow et al., 2014; Nguyen et al., 2016). The applications of non-thermal APPJ (NTAPPJ) are broad in the field of engineering and science that include polymer surface treatment,

* To whom correspondence should be addressed. sterilization, cleaning \& etching (Scholtz et al., 2015). In plasma medicine, argon plasma was applied clinically to cauterize living tissues exceeding room temperature (Watson et al., 2000; Kalghatgi et al., 2011). The thermal plasma induces intense heat to the tissues and the thermal property of plasma is difficult to be controlled (Vargo, 2004). Indeed, the intensity of the plasma products is determined by the degree of the electric field applied. Non-thermal plasma generates ions, photons $\&$ electrons at relatively lower temperatures or down to room temperature (Scholtz et al., 2015).

The applications of non-thermal plasma include sterilization of surfaces (Scholtz et al., 2015; Rizan et al., 2017) modifying the adhesion of cells (Kieft 
et al., 2006), to suppress invasiveness of cancer cells ( $\mathrm{Li}, 2016$ ), indirect treatment to cancer cells (Yan et al., 2015), application in wound healing (Haertel et al., 2014), drug delivery (Vijayarangan et al., 2018) and selectively killing cancer cells (Liu et al., 2017). Electrically controlled plasma exposes cells or tissues to different levels of charged particles, reactive gas species, radicals, UV photons, ozone, nitric oxide (NO), hydroxyl radicals $\left(\mathrm{OH}^{\circ}\right) \&$ singlet oxygen (Saadati et al., 2018). Previous studies (Chernyak et al., 2006; Kalghatgi et al., 2011; Laroussi, 2018) suggested that reactive oxygen species (ROS) formation by ionizing radiation is the major mechanism in damaging the DNA of cells (Kalghatgi et al., 2011). ROS may be actively transported across the bilayer cell membrane via a transient opening of pores in the membrane or calcium channels (Van der Paal et al., 2016). Hence, short-term exposure to plasma suppressed the migration and invasion of HeLa cells in a matrigel invasion assay ( $\mathrm{Li}$ et al., 2016). Furthermore, it was reported that plasma irradiated cells lost their ability to attach and incurred cellular changes (Kieft et al., 2004). The controllable plasma products enable different levels of applications, whether to modify the attachment of cells or to the extent of being destructive to the cells. Chemo-therapeutic active drug molecules are used to decipher signaling of the cell leading to deoxyribonucleic acid (DNA) damage. Many anticancer drugs for HeLa cells treatment are cytotoxic to normal cells leading to many side effects for the patient (Takara et al., 2005). Hence, a localized method for treating cancer cells are always of interest.

The modifiable non-thermal plasma in a different configuration such as dielectric barrier discharge (DBD), atmospheric pressure radiofrequency (RF) torch (Scholtz et al., 2015), DC pulsed power supplied APPJ (Dowling et al., 2011), zero voltage switching driver/flyback transformer APPJ (Mohd Zin et al., 2017), inductively coupled microplasma jet and, atom flow RF-plasma reactor (Mariotti et al., 2016) are simply appealing for a different area of applications. However, these systems are usually cumbersome and heavy. High voltage, up to several kilovolts $(\mathrm{kV})$, is needed for a non-thermal plasma system to discharge the plasma (Zerouali et al., 2014; Dowling et al., 2011). Non-thermal plasma density and intensity of compositions can be regulated to control the plasma discharge at atmospheric pressure. To have better control over the selectivity and effectiveness in killing targeted and non-targeted cells, the development of a flexible plasma-controlled system is required to extend the applications of non-thermal plasma in tissue treatment. Moreover, a portable and facile NTAPPJ system will broaden the applications of plasma in other biomedical areas.
A portable dimmer controlled NTAPPJ is reported in this work. The system consists of a quartz torch injected with argon gas and energized with a pair of charged copper electrodes. This system operates at low temperature in an ambient surrounding and is yet to be explored for the controlled treatment application to cancer cells. Also, we demonstrate that the proposed NTAPPJ discharged at different intensities could modulate different biophysical changes leading to the destruction of HeLa cancer cells. This work investigates the effects of AC power supply regulated by a dimmer circuit, leading to influencing the morphology and adhesion of cells.

\section{MATERIALS AND METHODS}

\section{Characterization of current, voltage \& optical emission}

The plasma jet system used in this work is similar to the dielectric barrier discharge configuration (Lin et al., 2017) in which a quartz tube as a dielectric barrier or known as a plasma torch is powered by the voltage supply from a pair of copper electrodes (Figure 1a). The cathode is made up of a rod copper electrode, which is inserted inside the plasma torch, while the anode is a ring electrode wrapped around the quartz tube. The quartz tube has an inner and outer diameter of 3 and $5 \mathrm{~mm}$, respectively. To ionize the argon gas at $40 \mathrm{~L} / \mathrm{min}$, flowing through the plasma torch, the tube was supplied with a maximum of $8 \mathrm{kVpp}$ and $60 \mathrm{~W}$ at $35 \mathrm{kHz}$ from a neon-transformer. The output voltage of the transformer was regulated by a dimmer circuit variable between $60-240 \mathrm{~V}$. The current, voltage $\&$ power at the output of the dimmer were determined using a hall-effect current power meter (PZEM-061, USA) and voltage probe (Tektronix P6015A, USA) linked to a digital oscilloscope (Agilent DSOX2022A, USA).

The element emitted from the plasma plume was quantitatively analyzed using glow-discharged optical emission spectroscopy (OES). The glow of the plasma plumed was focused using a focus lens in line-of-sight at a separation distance of $15 \mathrm{~mm}$ from an optical fiber sensor linked to a monochromator (Ocean Optic HR 4000). The wavelength of the plasma emission was determined in a spectra wavelength ranged between 200 to $1000 \mathrm{~nm}$. The measurements were acquired using Spectra Suite software.

\section{Cell culture and preparation for plasm treatment}

HeLa cell lines were obtained from ATCC (CLL-2, Virginia, USA) and cultured in a Petri dish at a density of $1.3 \times 10^{5}$ cells $/ \mathrm{mL}$. These cells were grown in a Dulbecco's Modified Eagle's Medium 


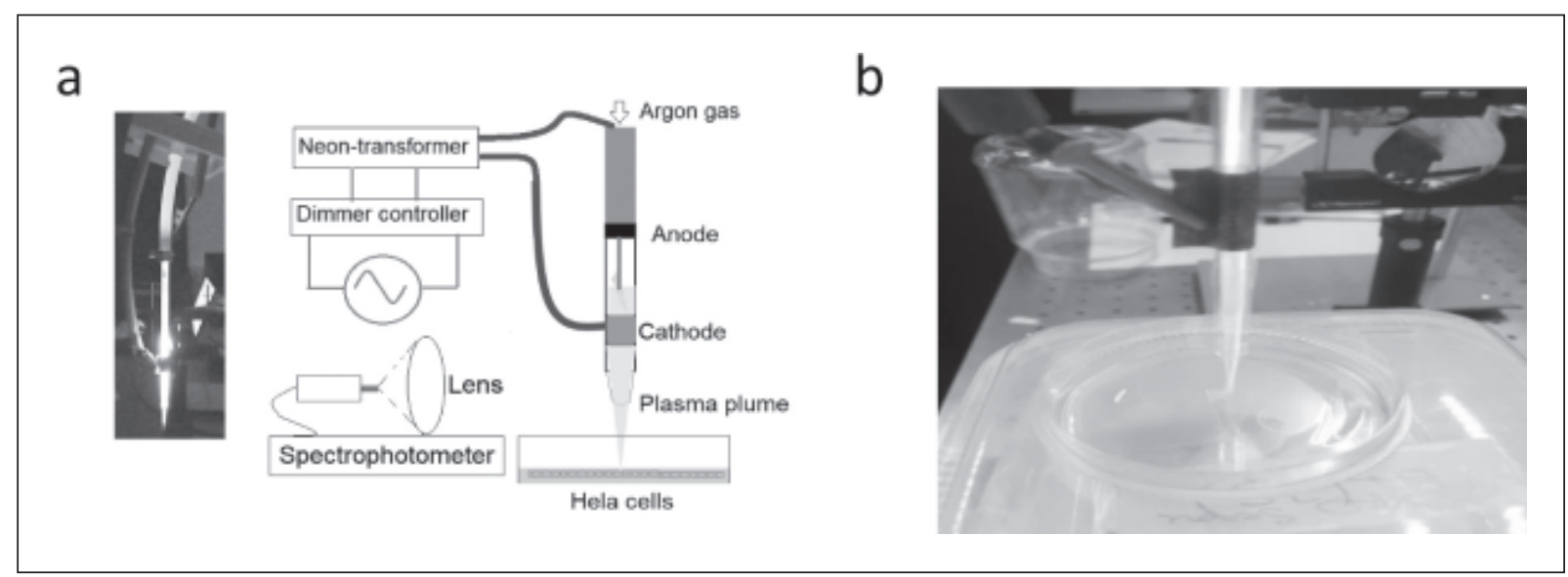

Fig. 1. (a) The setup of an OES measurement for an NTAPPJ system, (b) Plasma exposure to the monolayer of HeLa cells.

(DMEM) supplemented with 10\% Fetal Bovine Serum (Gibco®, Life Technologies, US), Penicillin/ streptomycin (100 units $/ \mathrm{mL}, 10 \mathrm{mg} / \mathrm{mL}$ SigmaAldrich, UK), L-Glutamine (Gibco®, Life Technologies, US) \& Fungizone $(2.5 \mathrm{mg} / \mathrm{L}$, Sigma-Aldrich, UK). The cells were then incubated in a $37^{\circ} \mathrm{C}$ incubator perfused with $5 \% \mathrm{CO}_{2}$. When the cells were nearing $80 \%$ confluency, the culture media was discarded \& the cells were rinsed with Hank's Balanced Salt Solution (HBSS). Subsequently, the cells in the Petri dish were added with $1 \mathrm{~mL}$ of complete DMEM before plasma treatment (Figure 1b).

\section{Plasma treatment to $\mathrm{HeLa}$ cells}

Plasma jet was produced using the NTAPPJ setup as shown in Figure 1. The plasma plume was directed to the cells immersed in $1 \mathrm{~mL}$ of culture media at a separation distance of $15 \mathrm{~mm}$. The varied dimmer voltage, in turn, changed the voltage supplied to the neon-transformer, energizing the plasma torch which was purged with argon as the carrier gas for plasma. The temperature of the plasma jet varied between 35 to $55^{\circ} \mathrm{C}$ according to the applied voltage of the dimmer (Mohd Zin et al., 2019). The effects of the plasma treatment on the cell morphology and adhesion were studied by varying the plasma emission adjustable at different dimmer voltage between $60-240 \mathrm{~V}$ for $20 \mathrm{sec}$. The photomicrographs of the cells before and after plasma treatments were captured using a phasecontrast microscope (Nikon eclipse T-100, Tokyo, Japan) and analyzed using QCapture software.

\section{Live and dead cells stainings of $\mathrm{HeLa}$ cells treated with the plasma jet}

The viability of the cells was further investigated using a staining kit (Invitrogen, Paisley, UK). Live and dead cells were stained using Calcein-AM (20 $\mu \mathrm{L}, 2 \mathrm{mM}$ in $10 \mathrm{~mL}$ HBSS) in green and ethidium homodimer-1 (EthD-1, $5 \mu \mathrm{L}, 4 \mathrm{mM}$ in $10 \mathrm{~mL}$ HBSS) in red. The controls and plasma-treated cells at different dimmer voltages (60 to $240 \mathrm{~V}$ ) were stained in the mixed reagents for $10 \mathrm{~min}$ before imaging in a BX53 fluorescence microscope (Olympus, Tokyo, Japan) linked to a DP73 chargedcoupled-device camera (Olympus, Tokyo, Japan). The plasma treatment and staining experiments were repeated three times.

\section{RESULTS AND DISCUSSION}

Figure 2 shows a typical phase angle output of a voltage dimmer supplied to the neon-transformer. The power produced is subjected to the on-time under the waveforms. The dimmer works both for resistive and inductive load assembled in the neontransformer. The effective root means square power delivered to the neon-transformer is adjustable by varying the phase angle of each alternating half cycle of the sinusoidal waveforms. At root-meansquare voltage (Vrms) of $60 \mathrm{~V}$, a major portion of the full cycle of a sinusoidal waveform was "cut off" while maintaining short on-time for a peak voltage in the waveform as shown in Figure 2a. This occurred to both positive and negative half-cycles of the phase angle waveforms. When the voltage was increased from 60 to $240 \mathrm{~V}$, the sinusoidal waveform gradually regained the full sinusoidal cycle at 240 $\mathrm{V}$ (Figure 2j). Hence, the modulation of the phase angle of the sinusoidal waveform changed the power delivered to the neon-transformer \& in turn, changing the electrical supply to the plasma torch. In addition to the three species; hydroxy radicals (OHÿ), nitrogen (N2) and argon (Ar) detected by the OES, UV, negative ions \& reactive oxygen species (ROS) were also produced (Jiang et al., 2014; Scholtz et al., 2015). 


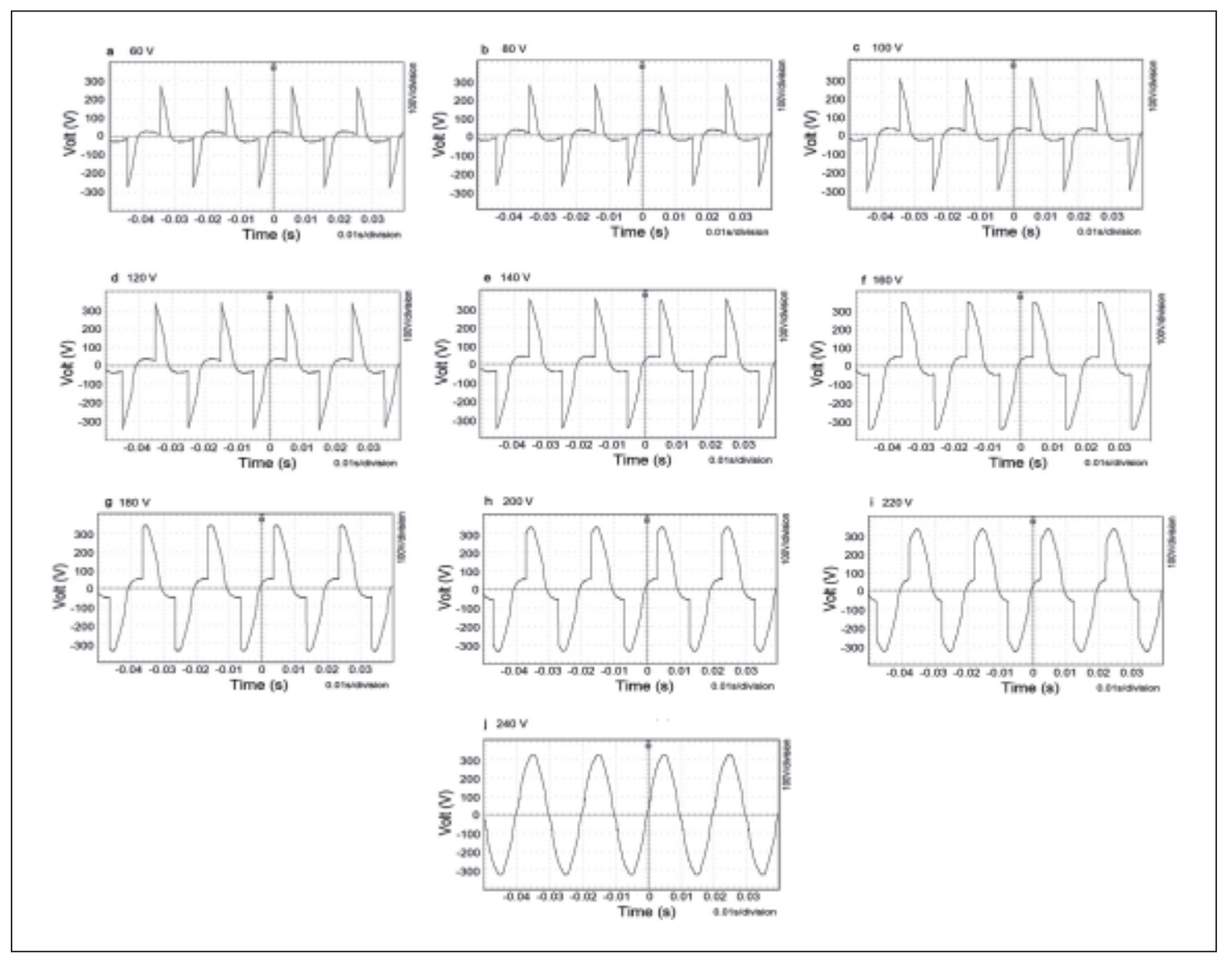

Fig. 2. Dimmer controllable voltages supplied to the neon-transformer at (a) $60 \mathrm{~V}$, (b) $80 \mathrm{~V}$, (c) $100 \mathrm{~V}$, (d) $120 \mathrm{~V}$, (e) $140 \mathrm{~V}$, (f) $160 \mathrm{~V}$, (g) $180 \mathrm{~V}$, (h) $200 \mathrm{~V}$, (i) $220 \mathrm{~V}$, and (j) $240 \mathrm{~V}$.

The electrical energy provided to the plasma torch is proportional to different gas species generated as revealed by the OES measurements (Figure 3). Correlatively, the intensity or the quantity of the argon, $\mathrm{OH}^{\circ}, \mathrm{O}_{2} \& \mathrm{~N}_{2}$ are regulated by the different power of the plasma torch. As shown in Figure 3a, a low level of OHÿ and Ar are detectable by the OES at 306 and $762 \mathrm{~nm}$, respectively. The spectra obtained are similar to a plasma jet of argon gas as reported previously (Jiang et al., 2014). The atomic lines for the $\mathrm{O}_{2}$ and $\mathrm{N}_{2}$ gases are more apparent at 777 and $335 \mathrm{~nm}$ (Figure 4(i)-(j)), respectively when the dimmer voltage was adjusted above $200 \mathrm{~V}$.

Figure 4 shows the power output of the dimmer. The output voltage of the dimmer was varied between 60 to $240 \mathrm{~V}$, corresponding to a power output of $8.4-83.6 \mathrm{~W}$ (Figure 4a). This in turn varied the power of the neon transformer delivered to the plasma torch at different energy levels. The increase of the dimmer voltage increased the ionization Ar gas, resulting in an increased density of $\mathrm{OH}^{\circ}, \mathrm{N}_{2} \& \mathrm{Ar}$ (Figure 4b). However, there was a small increase in $\mathrm{N}_{2}$ as compared to $\mathrm{Ar}$ and $\mathrm{OH}$ molecules directed to the culture media. A small peak appeared for $\mathrm{N}_{2}$ over the increased voltage, indicating that $\mathrm{N}_{2}$ gas is less excitable in the Ar carrier gas.

At lower dimmer voltage $<80 \mathrm{~V}$ or $<20 \mathrm{Watt}$, the cells remained attached to the surface of the Petri dish similar to the morphology of control, shown in Figure 5. However, the cells were found round-off with a smaller cell adhesion area at an applied voltage between $80-100 \mathrm{~V}$ (Figure 5b-f). Any plasma produced at a voltage greater than 80 $\mathrm{V}$ induced damaging effects to the cell membranes.

For plasma treatment at a dimmer voltage above $140 \mathrm{~V}$, shattered cell membranes and fragments of broken membranes were observed. This might be associated with cell surface blebbing and breakage of actin filaments (Lee \& Kim, 2016). Also, a previous study suggested that the ROS could impose oxidative stress on the cells and dissociating cell membrane proteins (Lin et al., 2017).

However, it is difficult to identify the viability of the cells treated with plasma based on the phase contrast microscopy images even though they seemed to be physically intact on the plastic surface. In live/dead cell stainings (Figure 6a-b), plasmatreated HeLa cells produced from a dimmer voltage less than $60 \mathrm{~V}$ remained viable similar to the control. Plasma treatment at a dimmer voltage of 


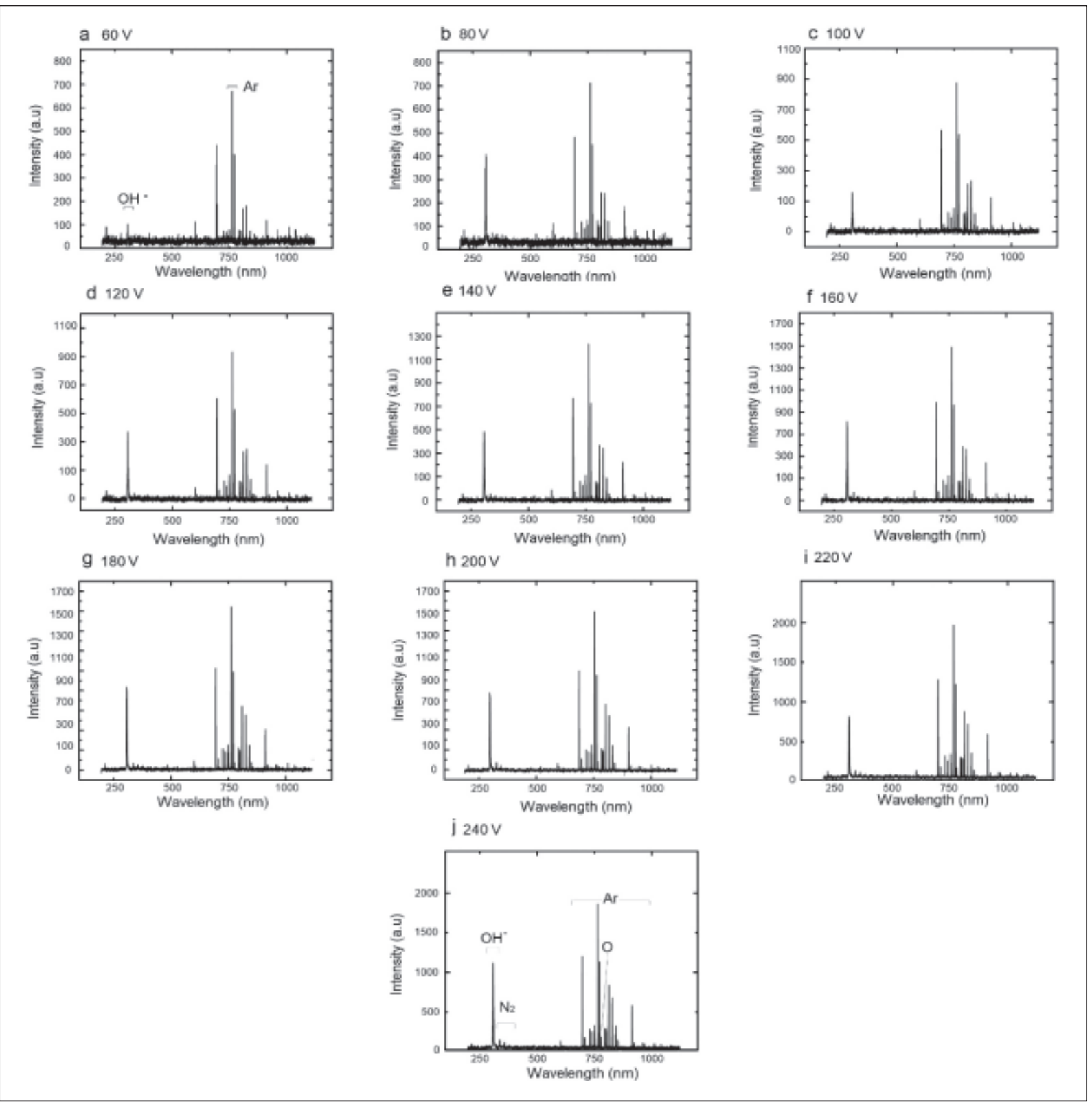

Fig. 3. OES output measured for dimmer voltage set at (a) $60 \mathrm{~V}$, (b) $80 \mathrm{~V}$, (c) $100 \mathrm{~V}$, (d) $120 \mathrm{~V}$, (e) $140 \mathrm{~V}$, (f) $160 \mathrm{~V}$, (g) $180 \mathrm{~V}$, (h) $200 \mathrm{~V}$, (i) $220 \mathrm{~V}$, and (j) $240 \mathrm{~V}$.

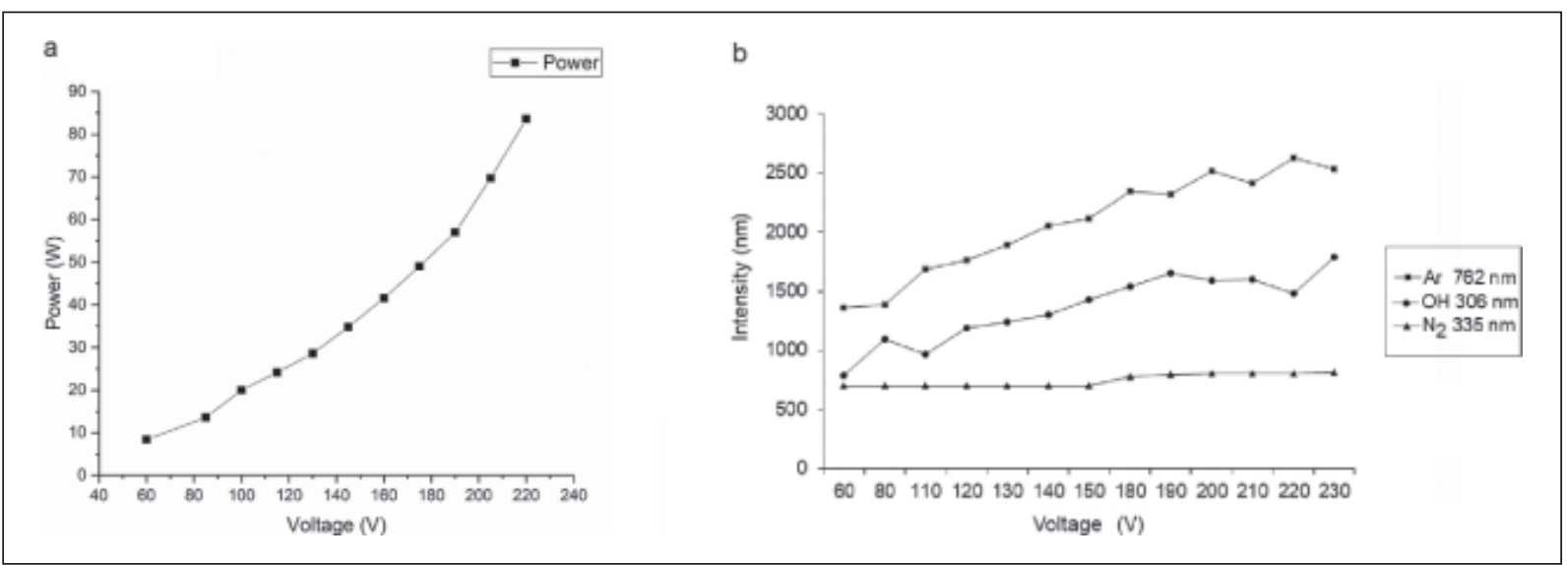

Fig. 4. (a) The relationship of voltage and power output of the dimmer, (b) The intensity output of different species of the plasma interacted with the atmospheric air. 


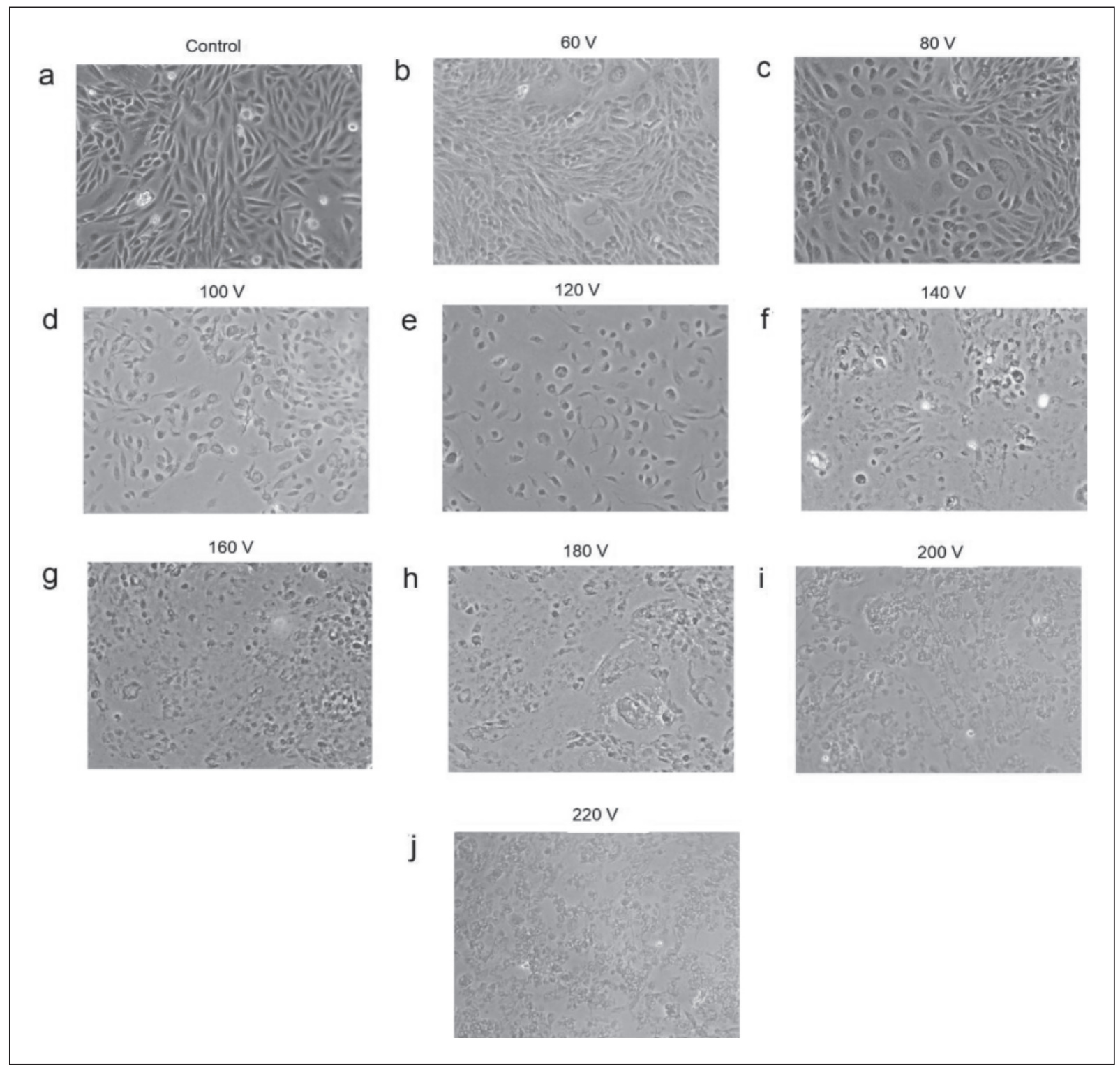

Fig. 5. Effects of different controlled voltage at (a) control, (b) $60 \mathrm{~V}$, (c) $80 \mathrm{~V}$, (d) $100 \mathrm{~V}$, (e) $120 \mathrm{~V}$, (f) $140 \mathrm{~V}$, (g) $160 \mathrm{~V}$, (h) $180 \mathrm{~V}$, (i) $200 \mathrm{~V}$, and (j) $220 \mathrm{~V}$ to the plasma treatment of HeLa cells.

$80 \mathrm{~V}$ is cytotoxic causing approximately half of the cells to enter apoptosis (stained in red). The attachment of the live cells was much reduced with retracted filopodia and lamellipodia as seen in Figure 6c. This observation is supported by a previous report which revealed that short-term NTAPPJ could inhibit the signaling pathway associated with invasion and metastasis of HeLa cells (Li et al., 2016). However, our study underpinning that the power applied to generate atmospheric plasma is a crucial factor in inhibiting cell adhesion despite short term plasma exposure to cells. The cells remained attached and round.

As observed in Figures 3 and $4 b$, there is an increase of $\mathrm{OH}^{\bullet}$ proportional to the dimmer voltage adjusted from $80-240 \mathrm{~V}$. A previous report (Attri et al., 2015) revealed that plasma-activated UV- photolysis could induce the generation of hydroxyl radicals $\left(\mathrm{OH}^{\circ}\right)$ and hydrogen peroxide in biosolutions. The hydrogen peroxide at the ambient air phase is produced via the process of $\mathrm{OH}^{\bullet}+\mathrm{OH}^{\bullet} \rightarrow$ $\mathrm{H}_{2} \mathrm{O}_{2}$. This reaction could also produce $\mathrm{H}_{2} \mathrm{O}+\mathrm{O}$. When UV interacted with the $\mathrm{H}_{2} \mathrm{O}$ in the media (UV $\left.+\mathrm{H}_{2} \mathrm{O} \rightarrow \mathrm{H}_{2} \mathrm{O}^{*}\right)$, the $\mathrm{H}_{2} \mathrm{O}^{*}$ will be converted into $\mathrm{OH}^{-}$and $\mathrm{H}^{+}$in the culture media (Attri et al., 2015). In turn, the $\mathrm{OH}^{-}+\mathrm{OH}^{-}$produce $\mathrm{H}_{2} \mathrm{O}_{2}+2 \mathrm{e}^{-}$. Hence, the bombardment of the plasma to the culture media increased the major reactive species of hydroxyl radicals and hydrogen peroxide within. Both species are well-studied toxins to cells (Mahaseth \& Andrei, 2017). Reduced attachment of cells and cell death can be explained by the detrimental effects of UV and free radicals produced at a dimmer voltage above $80 \mathrm{~V}$. 


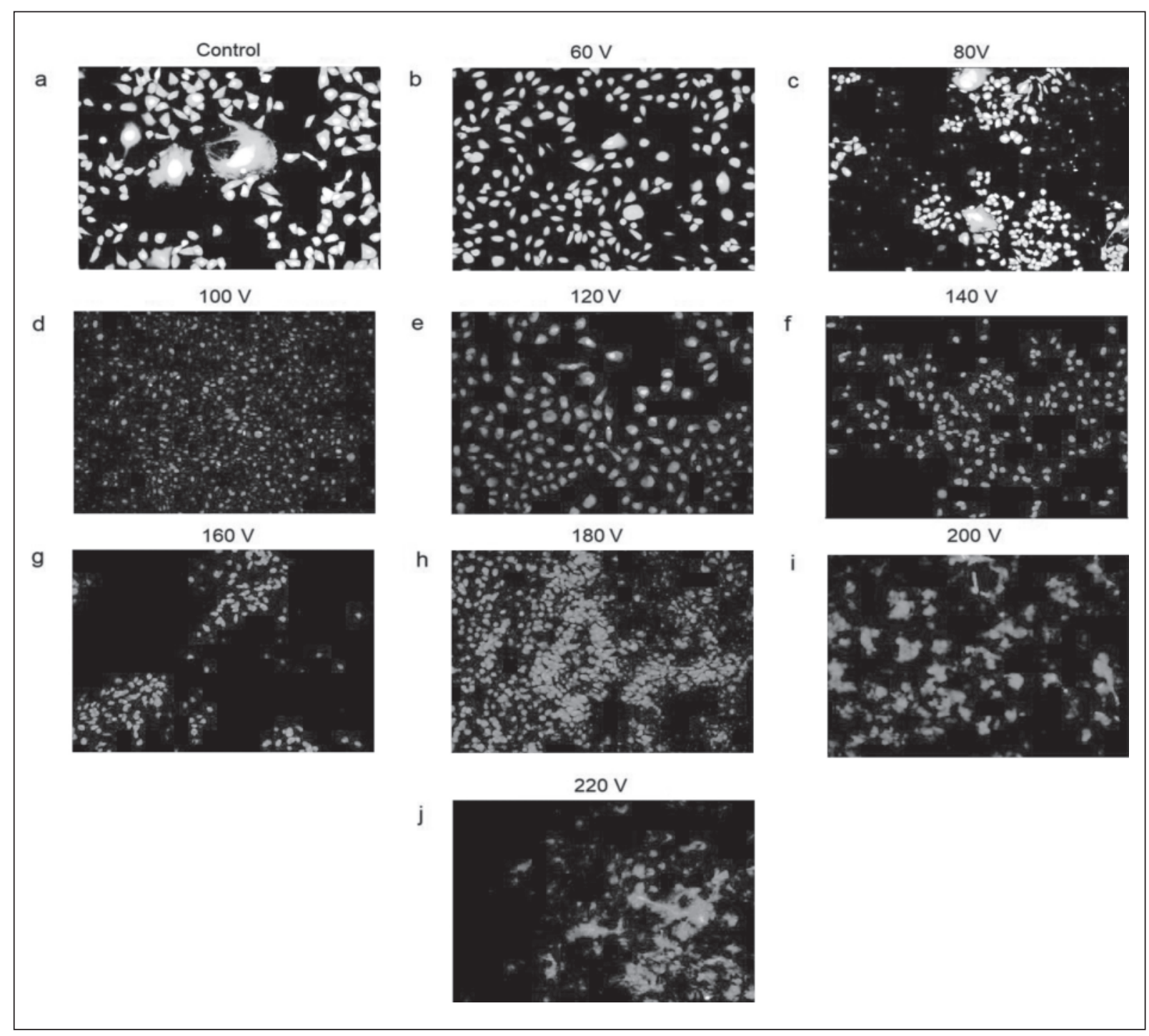

Fig. 6. Fluorescence stainings of live and dead HeLa cells treated at different dimmer voltages of (a) control, (b) $60 \mathrm{~V}$, (c) $80 \mathrm{~V}$, (d) $100 \mathrm{~V}$, (e) $120 \mathrm{~V}$, (f) $140 \mathrm{~V}$, (g) $160 \mathrm{~V}$, (h) $180 \mathrm{~V}$, (i) $200 \mathrm{~V}$, and (j) $220 \mathrm{~V}$.

The dimmer voltage applied is proportional to the density of the plasma products at a short treatment time of $20 \mathrm{~s}$ (Figure $4 \mathrm{~b}$ ). The temperature of the plasma plume released was about 35 to $50^{\circ} \mathrm{C}$ for the first $20 \mathrm{~s}$ of operation (Lin et al., 2017). However, the treatment time is also an important factor in regulating the dosage of ROS released (Lee \& Kim, 2016). The results indicated that the NTAPPJ system based on dimmer control produced tunable charged species and photon energy, that induced a different level of effects to the biophysical characteristics of cells, ranging from reduced cell adhesion to apoptosis and eventually cell membrane destructions. It is postulated that the controllable intensity of plasma discharges might be applicable in damaging the cancer cells while offering reduced effects to the surrounding normal tissues.

\section{CONCLUSION}

The plasma system based on the dimmer circuit and neon transformer provide controllable power, which in turn regulates the intensity of plasma discharges. Different species of $\mathrm{Ar}, \mathrm{N}_{2}, \mathrm{OH}^{*} \& \mathrm{O}$ were identified in the optical emission spectra, but the existence of $\mathrm{N}$ and $\mathrm{O}$ atomic lines were subjected to higher dimmer voltage above $100 \mathrm{~V}$. The controlled power output corresponding to the controlled intensity of gas species discharges are essential for different levels of treatments. Photon energy, oxidative stress $\&$ ROS of the plasma discharges produced above $80 \mathrm{~V}$ of dimmer voltage might be the main factors inducing detrimental effects on the biophysical structures of the cells. However, the cells were found viable and well spread for plasma treatment below a dimmer voltage of less than $80 \mathrm{~V}$ or $20 \mathrm{~W}$. The 
system presented is useful in modulating the cell adhesion, causing cell fatality or breaking down of cell membranes.

\section{ACKNOWLEDGEMENTS}

The authors are grateful to the research grant awarded by Universiti Tun Hussein Onn Malaysia (GPPS Grant Vot. No. U707) and the technical support received from Faezahana Mokhter.

\section{REFERENCES}

Attri, P., Kim, Y.H., Park, D.H., Park, J.H., Hong, Y.J., Uhm, H.S., Kim, K.-N., Fridman, A. \& Choi, E.H. 2015. Generation mechanism of hydroxy radical species and its lifetime prediction during the plasma-initiated ultraviolet (UV) photolysis. Scientific Reports, 5: 9332.

Chernyak, B.V., Izyumov, D.S., Lyamzaev, K.G., Pashkovskaya, A.A., Pletjushkina, O.Y., Antonenko, Y.N., Sakharov, D.V., Wirtz, K.W.A. \& Skulachev, V.P. 2006. Production of reactive oxygen species in mitochondria of HeLa cells under oxidative stress. Biochimica et Biophysica Acta, 1757(5 \& 6): 525-534.

Dowling, D.P., O’Neill, F., Langlais, S.J. \& Law, V.J. 2011. Influence of DC pulsed atmospheric pressure plasma jet processing conditions on polymer. Activation Plasma Process Polymer, 8(8): 718-727.

Haertel, B., Woedtke, T.V., Weltmann, K.-D. \& Lindequist, U. 2014. Biomolecules \& Therapeutics, 22(6): 477-490.

Jiang, W., Tang, J., Wang, Y., Zhao, W. \& Duan, Y. 2014. Characterization of argon direct-current glow discharge with a longitudinal electric field applied at ambient air Scientific Report, 4: 6323.

Kalghatgi, S., Kelly, C.M., Cerchar, E., Torabi, B., Alekseev, O., Fridman, A., Friedman, G. \& Azizkhan-Clifford, J. 2011. Effects of nonthermal plasma on mammalian cells. PLoS One, 6(1): e16270.

Kieft, I.E., Broers, J.L., Caubet-Hilloutou, V., Slaaf, D.W., Ramaekers, F.C. \& Stoffels, E. 2004. Electric discharge plasmas influence attachment of cultured CHO K1 cells. Bioelectromagnetics, 25(5): 362-8.

Kieft, I.E., Kurdi, M. \& Stoffels, E. 2006. Reattachment and apoptosis after plasma-needle treatment of cultured cells. IEEE Transactions on Plasma Science, 34(4): 1331-1336.

Laroussi, M. 2018. Plasma medicine: a brief introduction. Plasma, 1(1): 1-14.
Lee, J.-H. \& Kim, K.-N. 2016. Effects of a nonthermal atmospheric pressure plasma jet on human gingival fibroblasts for biomedical application. BioMed Research International, 2016: 1-9.

Li, W., Yu, K.N., Bao, L., Shen, J., Cheng, C. \& Han, W. 2016. Non-thermal plasma inhibits human cervical cancer HeLa cells invasiveness by suppressing the MAPK pathway and decreasing matrix metalloproteinase-9 expression. Scientific Reports, 6(19720): 1-11.

Lin, A., Truong, B., Patel, S., Kaushik, N., Choi, E.H., Fridman, A. Fridman, G. \& Miller, V. 2017. Nanosecond-pulsed DBD plasma-generated reactive oxygen species trigger immunogenic cell death in A549 lung carcinoma cells through intracellular oxidative stress. International Journal of Molecular Sciences, 18(5): 966.

Liu, Y., Tan, S., Zhang, H., Kong, X., Ding, L, Shen, J., Lan, Y., Cheng, C., Zhu, T. \& Xia, W. 2017. Selective effects of non-thermal atmospheric plasma on triplenegative breast normal and carcinoma cells through different cell signaling pathways. Scientific Reports, 7(7980): 1-12.

Mahaseth, T. \& Andrei, K. 2017. Potentiation of hydrogen peroxide toxicity: From catalase inhibition to stable DNA-iron complexes. Mutation Research, 773: 274-281.

Mariotti, D., Belmonte, T., Benedikt, J., Velusamy, T., Jain, G. \& Svrcek, V. 2016. Low-temperature atmospheric pressure plasma processes for "Green" third generation photovoltaics. Plasma Processes and Polymers, 13(1): 70-90.

Mohd Zin, R., Soon, C.F., Ab Sani, M.Z., Rizon, E.R., Tee, K.S., Ahmad, M.K., Ahmad, N.N., Mat Jubadi, W. \& Nayan, N. 2017. Zero voltage switching driver and flyback transformer for generation of atmospheric pressure plasma jet. AIP Conference Proceedings, 1883(1): 020023.

Mohd Zin, R., Soon, C.F., Mohd Yusof, N., Rizon, E.R., Morsin, M., Ahmad, M.K. \& Nayan, N. 2019. Dimmer and neon transformer as a power controllable generator for atmospheric pressure plasma jet. International Journal of Power Electronics and Drive System (IJPEDS), 10(2): 594-601.

Nguyen, N.H., Park, H.J., Yang, S.S., Choi, K.S. \& Lee, J.-S. 2016. Anti-cancer efficacy of nonthermal plasma dissolved in a liquid, liquid plasma in heterogeneous cancer cells. Scientific Reports, 6(29020): 1-14.

Rizan, R.E., Ahmad, M.K., Soon, C.F., Sahdan, M.Z., Lias, J., Wibowo, K.M., Abu Bakar, A.S., Md Arshad, M.K., Hashim, U. \& Nayan, N. 2017. Development of atmospheric pressure plasma needle jet for sterilization applications. AIP Conference Proceedings, 1883(1): 020025. 
Saadati, F., Mahdikia, H., Abbaszadeh, H.-A., Abdollahifar, M.-A., Khoramgah, M.S. \& Babak, S. 2018. Comparison of direct and indirect cold atmospheric-pressure plasma methods in the B16F10 melanoma cancer cells treatment. Scientific Report, 8(1): 1-13.

Scholtz, V., Pazlarova, J., Souskova, H., Josef, K. \& Julak, J. 2015. Nonthermal plasma - a tool for decontamination and disinfection. Biotechnology Advances, 33(6): 1108-1119.

Siow, K.S., Kumar, S. \& Griesser, H.J. 2014. Lowpressure plasma methods for generating nonreactive hydrophilic and hydrogel-like biointerface coatings - a review. Plasma Processes and Polymers, 12(1): 8-24.

Takara, K., Sakaeda, T., Yagami, T., Kobayashi, H., Ohmoto, N., Horinouchi, M., Nishiguchi, K. \& Okumura, K. 2005. Cytotoxic effects of 27 anticancer drugs in HeLa and MDR1overexpressing derivative cell lines. Biological and Pharmaceutical Bulletin, 25(6): 771-778.

Van der Paal, J., Neyts, E.C., Verlackt, C.C.W. \& Bogaerts, A. 2016. Effect of lipid peroxidation on membrane permeability of cancer and normal cells subjected to oxidative stress. Chemical Science, 7(1): 489-498.
Vargo, J.J. 2004. Clinical applications of the argon plasma coagulator. Gastrointestinal Endoscopy, 59(1): 81-88.

Vijayarangan, V., Delalande, A., Dozias, S., Pouvesle, J.-M., Pichon, C. \& Robert, E. 2018. Cold atmospheric plasma parameters investigation for efficient drug delivery in HeLa cells. IEEE Transactions on Radiation and Plasma Medical Sciences, 2(2): 109-115.

Watson, J.P., Bennett, M.K., Griffin, M. \& Matthewson, K. 2000. The tissue effect of argon plasma coagulation on esophageal and gastric mucosa. Gastrointestinal Endoscopy, 52(3): 342-345.

Yan, D., Talbot, A., Nourmohammadi, N., Cheng, X., Canady, J., Sherman, J. \& Keidar, M. 2015. Principles of using cold atmospheric plasma stimulated media for cancer treatment. Scientific Reports, 5(18339): 1-17.

Zerouali, S., Hamida, A.H. \& Belloufi, M. 2014. Non-linear control techniques applied to high frequency inverters for induction plasma generator. International Journal of Advanced Science and Technology, 69: 33-46. 
